\title{
Analysis of Production, Yield and Cultivation Area Trends in Major Cereal Crops in Ethiopia
}

\author{
Workneh Bekere Kenea \\ Ethiopian Institute of Agricultural Research, Jimma Research Center, Jimma, Ethiopia
}

\section{Email address:}

keneni02@yahoo.com

\section{To cite this article:}

Workneh Bekere Kenea. Analysis of Production, Yield and Cultivation Area Trends in Major Cereal Crops in Ethiopia. Agriculture, Forestry and Fisheries. Vol. 10, No. 4, 2021, pp. 123-126. doi: 10.11648/j.aff.20211004.11

Received: May 4, 2021; Accepted: July 2, 2021; Published: July 13, 2021

\begin{abstract}
Cereals are important crops for achieving food security in Ethiopia. Maize, sorghum and millet are major cereal grown by smallholder farmers of the country for consumption. Fifteen (15) years data of total production, yield and cultivated area of these cereal crops in Ethiopia were assessed from http://www.fao.org/faostat/en/ to understand the trends of production, yield and cultivated area of maize, sorghum and millet through time and analyze the contribution of increasing yield and cultivated area for total production at the country level. The result revealed that total production in 1993-2019 was increased by $560 \%, 736 \%$ and $732 \%$ in maize, sorghum and millet respectively whereas cultivated area for these crops in the same period was increased by $170 \%, 304 \%$ and $159 \%$. Yield of maize, sorghum and millet in 2019 years was $147 \%$, 107\% and $222 \%$ respectively more compared to the yield of the respective crops in the base year. In maize and sorghum, a unit increase of yield was associated with 3 million tons of production, and in millet a unit increase in yield was associated to nearly 5.5 million tones production. In conclusion, both yield increase and cultivation area expansion contributed to production increase but strong relation was observed between yield and total production in maize, sorghum and millet in Ethiopia.
\end{abstract}

Keywords: Cereals, Correlation, Ethiopia, Simple Linear Regression

\section{Introduction}

Ethiopian's growth and development is largely based on agriculture. Population of the country is currently approaching to 112 million and it is projected to be 188 million by 2050 [8]. Supporting this huge population in the future is possible by increasing cereal production to a threefold [11]. Grain self sufficiency in Ethiopia can be achieved by tripling cereal production such as maize, sorghum and millet in the country using improved technologies [11, 15]. This three-fold increase in production is possible by growing improved and high yielding crop varieties with good crop husbandry. However, increasing productivity with better resource use efficiencies such as fertilizer, land, herbicide which is the so called sustainable intensification is getting popularity worldwide. Though, these practices are currently a priority areas for achieving food self sufficiency in Ethiopian context, there is also an argument that production can be increased with an expansion of cultivation area of crops. Studies find out that bringing more land under cultivation in sub-Saharan Africa is associated with releasing more greenhouse gasses that exacerbate climate change [14] to some extent. High investment has been made in agricultural research for development in Ethiopia in the previous twenty years in cereal crops like maize, for example in genetic improvement, agronomy and plant nutrition and in its extension system [1] which enable better adoption of improved technologies [10]. As a result, yield of the crop [4, 12] and its cultivation area have been increased hand in hand that contributed to total production increase in the country. However, the relations of yield and total cereal production as well as cultivation area with total cereal production in Ethiopia were not well understood in quantitative terms. The objectives of this paper are therefore (1) to understand the trend in total production, cultivation area and yield of maize, sorghum and millet with time and (2) to quantify the contribution of yield and cultivation area to total production of these cereals in Ethiopia in fifteen years during 19932015 . 


\section{Methodology}

Data on crop production, yield and cultivated area of maize, sorghum and millet for 15 years (1993-2019) were retrieved from http://www.fao.org/faostat/en/ [9]. These data were plotted against years to see their trends though time. Then, yield and cultivated area of maize, sorghum and millet were related with total production of these crops to quantify their relative contribution to production. Correlation $\left(\mathrm{R}^{2}\right)$ and simple linear regression model were used to quantify the contribution of yield and area expansion for maize, sorghum and millet production increase at the country level.

\section{Results and Discussion}

Figure 1 shows the trends of total production and cultivation area for maize, sorghum and millet in Ethiopia whereas Figure 2 shows yield trends of these crops during
1993-2019 time. The result showed that total production of maize, sorghum and millet in 2019 was increased by $560 \%$, $736 \%$ and $732 \%$ compared to the production of the respective crops in 1993. The cultivated area of maize, sorghum and millet in 2019 year was $170 \%, 304 \%$ and $159 \%$ more than the cultivated area of these crops in 1993.

Yield of maize, sorghum and millet in 2019 years was $147 \%, 107 \%$ and $222 \%$ respectively compared to the yield of the respective crops in the base year (1993). The increase in production, cultivation area and yield of cereal crops (in FAO data base) agree with reports of central statistical agency of Ethiopia [5, 6, 7] and International Food Policy Research Institute (IFPRI) [2, 3, 13]. The trends in yield and cultivation area during this time (1993-2019) show that yield increase outweighs the cultivation area expansion only for millet and cultivation area increase for maize and sorghum was more than the yield increase of these crops in Ethiopia.
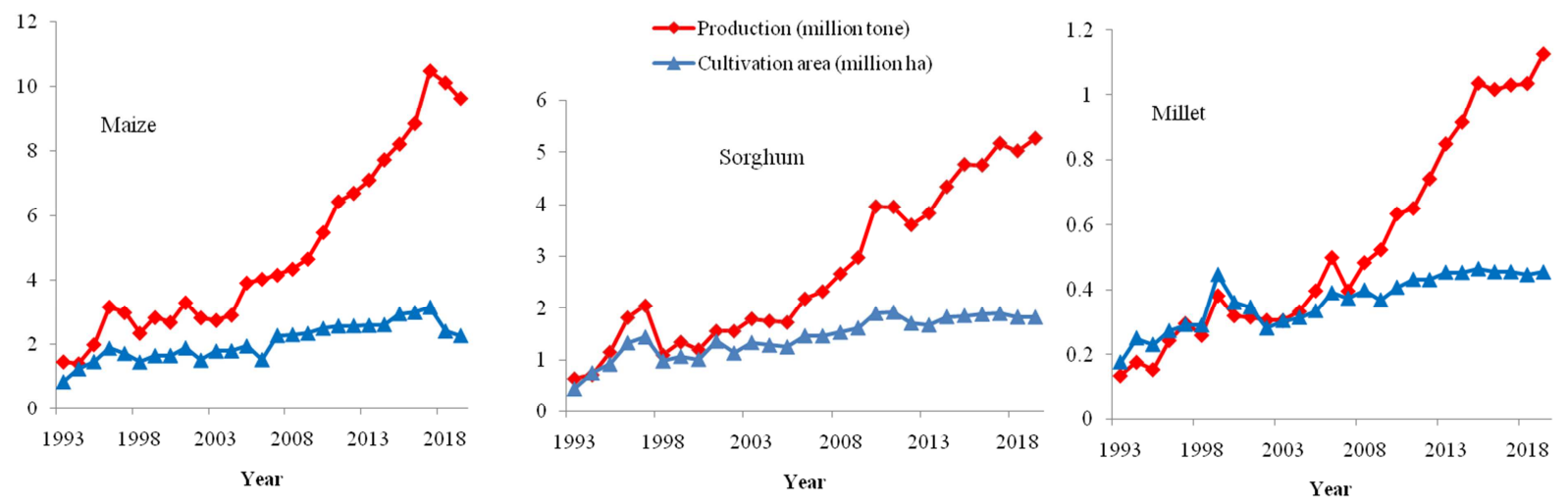

Figure 1. Trend of total production and cultivated area of maize, sorghum and millet for the period 1993-2019 in Ethiopia.

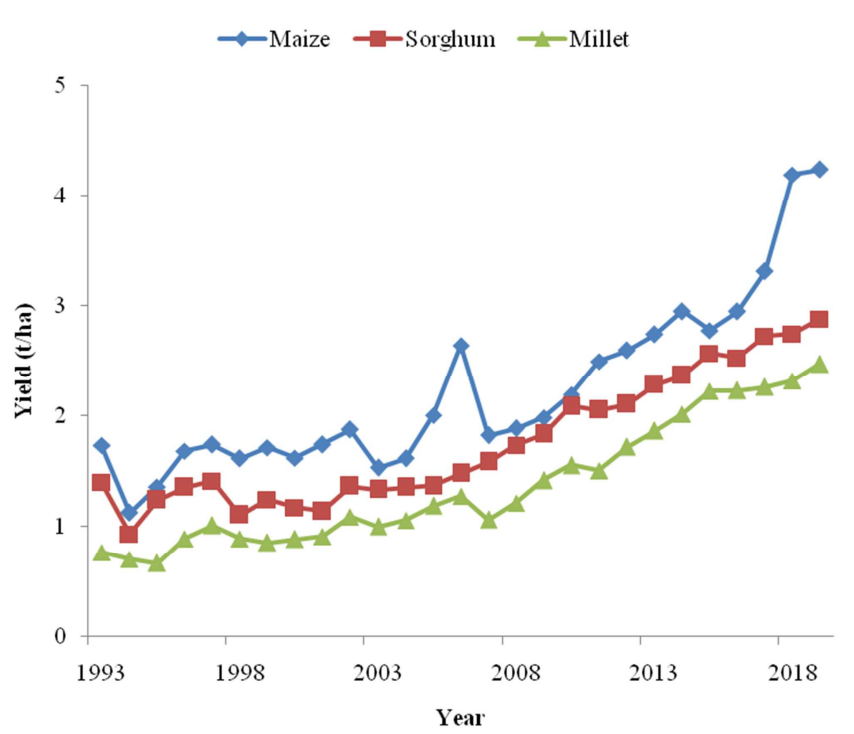

Figure 2. Maize, Sorghum and millet yield trend in Ethiopia for the period 1993-2019.

Maize production linearly increased in 15 years with productivity (Figure 3 ). The total production is highly correlated with productivity $\left(\mathrm{R}^{2}=0.87\right)$. The regression analysis showed that a unit $(1 \mathrm{t} / \mathrm{ha})$ productivity resulted in 1 million tons maize production at the country level. However, the correlation of area expansion and total maize production was moderate $\left(\mathrm{R}^{2}=0.77\right)$ compared to the correlation of productivity and total production. A unit (1 hectare) increase in cultivation area resulted in only 0.4 tone maize production in the country (Figure 3).

In sorghum (Figure 4), stronger correlations were observed than maize for both yield versus total production $\left(\mathrm{R}^{2}=0.96\right)$ and cultivated area versus total production $\left(\mathrm{R}^{2}=0.84\right)$. With a similar trend in maize production, a unit increase of sorghum yield ( $1 \mathrm{t} / \mathrm{ha}$ ) was associated with 3 million tons of sorghum production whereas a million hectare increase in cultivation area was resulted in 1.2 million tons of sorghum production increase at the country level (Figure 4).

The relation of yield and production of millet (Figure 5) was the strongest $\left(\mathrm{R}^{2}=0.98\right)$ compared to the relation assessed in maize and sorghum crops. However, the relation of cultivation area and total production of millet in Ethiopia during 1993-2019 was comparable $\left(\mathrm{R}^{2}=0.75\right)$ with the relation of maize area expansion and maize total production area (see Figure 3 and Figure 5). The relation of cultivation area with total production showed curve linear due to the fact that it is not only area expansion that increase production but also the increase in productivity per unit area through time. 

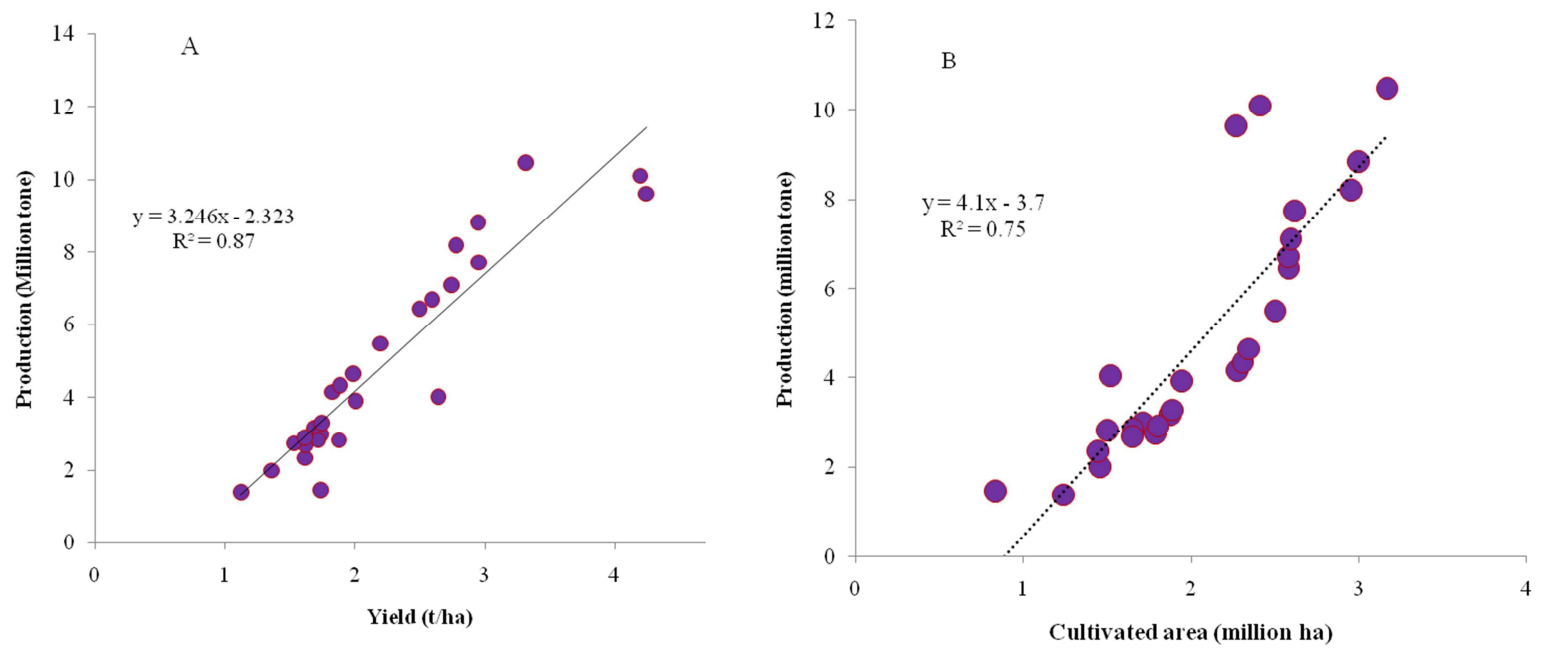

Figure 3. Relation of maize yield and maize total production (A) and maize cultivated area and total production (B) in Ethiopia in 1993-2019.
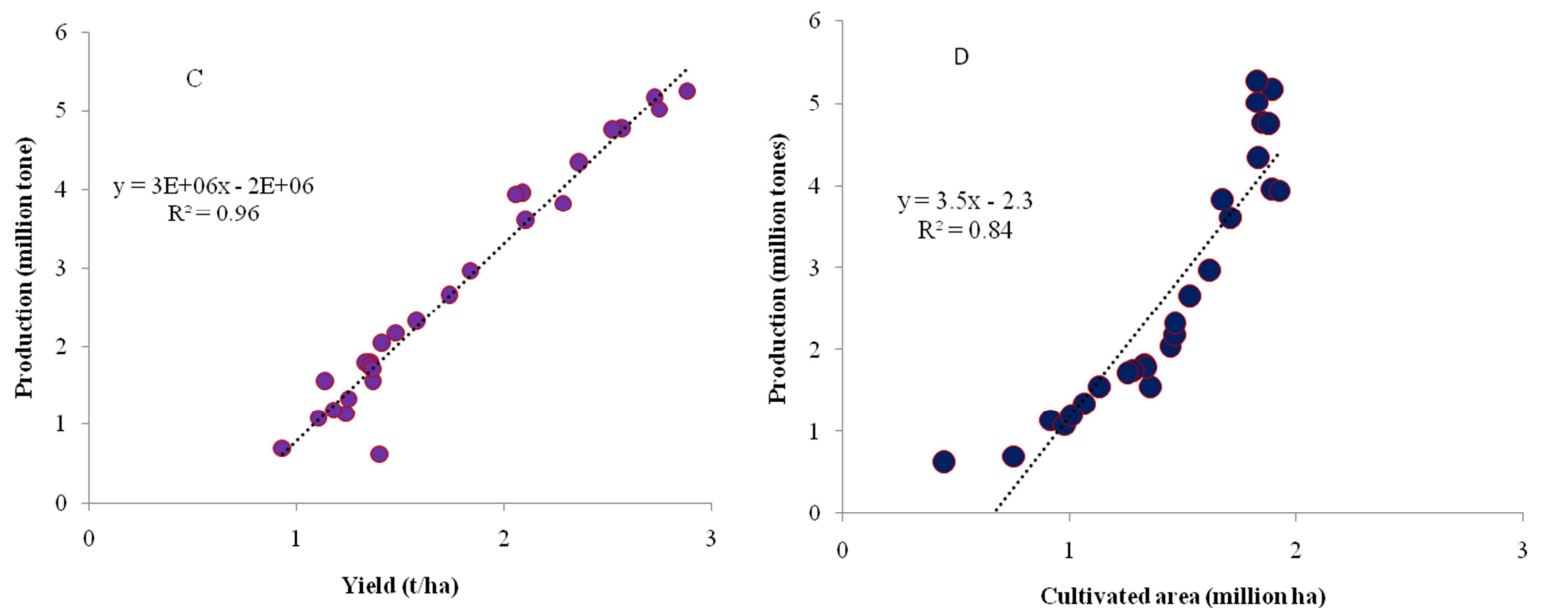

Figure 4. Relation of sorghum yield and sorghum total production (C) and sorghum cultivated area and total sorghum production (D) in Ethiopia in 19932019.
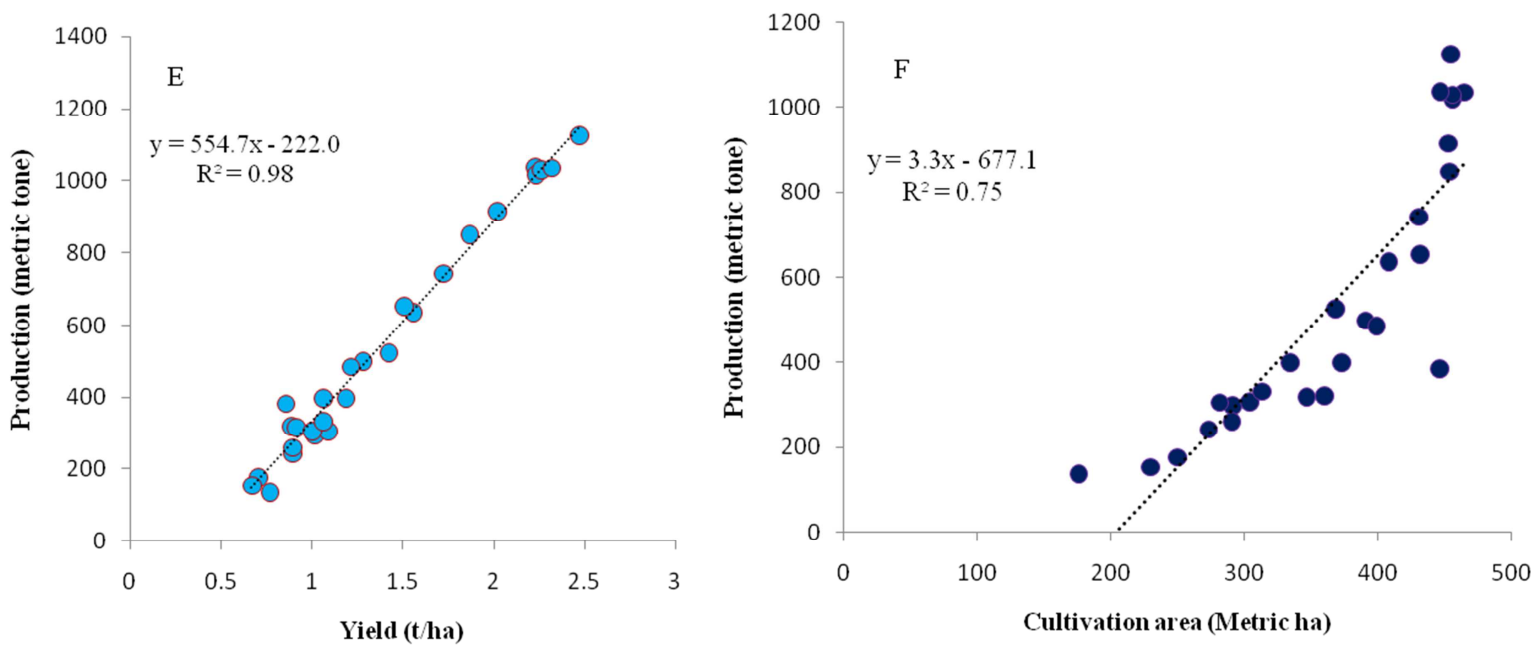

Figure 5. Relation of millet yield and millet total production (E) and millet cultivated area and total millet production (F) in Ethiopia in 1993-2019.

\section{Conclusion}

Production, yield and cultivation area of maize, sorghum and millet in 1993-2019 were assessed in Ethiopia. The relation of total production of these cereals with the yield achieved per unit area as well as with their cultivation area was quantified through correlation and linear regression. The analysis showed that, total production of maize, sorghum and 
millet in 2019 increased by $560 \%, 736 \%$ and $732 \%$ compared to the production in 1993 whereas cultivation areas of these crops was increased by $170 \%, 304 \%$ and $159 \%$ respectively. The yield of maize, sorghum and millet in 2019 was $147 \%, 107 \%$ and $222 \%$ more than the yield of the crops in 1993. The analysis showed that increasing yield per unit area contributed more than the contribution of area expansion in all the crops (maize, sorghum and millet). During 19932019, yield increase outweighs cultivation area expansion for millet but for maize and sorghum, cultivation area expansion was higher than yield increase. From the result, yield of the crops are likely to increase whereas, the cultivation area expansion is not an option for sufficient cereal production. Simple linear regression model explain and quantify the relation between yield and total production, whereas multilinear regression better fit to quantify the relation of cultivation area with total production than linear regression.

\section{References}

[1] Abate, T., B. Shiferaw, A. Menkir, W. Dagne, Y. Kebede, T. Kindie, M. Kassie, B. Gezahegn, T. Berhanu, and K. Tolera. 2015. Factors that transformed maize productivity in Ethiopia. Food Security 7: 965-981.

[2] Alemayehu ST, Dorosh P, Gemessa SA. 2013. Crop production in Ethiopia: regional patterns and trends University of Pennsylvania Press. pp. 53-83.

[3] Byerlee D, Spielman DJ, Alemu D, and Gautam M. 2007. Policies to Promote Cereal Intensification in Ethiopia: A Review of Evidence and Experience. IFPRI Discussion Paper 00707. Washington, D C: International Food Policy Research Institute.

[4] Cochrane, L., Bekele, Y. W., 2018. Average crop yield (20012017) in Ethiopia: Trends at national, regional and zonal levels. Data in Brief, 16, 1025-1033.

[5] CSA, Ethiopia, 2018. Agricultural sample survey 2014/2015 (2007 E. C). Report on Area and Production of Crops (Private Peasant Holdings, Mehere Season). Central Statistical agency, Ethiopia, Addis Ababa.
[6] CSA, Ethiopia, 2019. Agricultural sample survey 2014/2015 (2008 E. C). Report on Area and Production of Crops (Private Peasant Holdings, Mehere Season). Central Statistical agency, Ethiopia, Addis Ababa.

[7] CSA, Ethiopia, 2020. Agricultural sample survey 2014/2015 (2009 E. C). Report on Area and Production of Crops (Private Peasant Holdings, Mehere Season). Central Statistical agency, Ethiopia, Addis Ababa.

[8] FAOSTAT. 2019. Food and Agriculture organization. http://www.fao.org/faostat/en/

[9] FAOSTAT. 2020. Food and Agriculture organization. http://www.fao.org/faostat/en/

[10] Howard J, Crawford E, Kelly V, Demeke M, Jeje JJ. 2003. Promoting High-Input Maize Technologies in Africa: The Sasakawa-Global 2000 Experience in Ethiopia and Mozambique. Food Policy 28: 335-348.

[11] Kindie TF, van Ittersum MK, Wiebe KD, Boogaard H, Radeny M, Solomon D. 2018. Can Ethiopia feed itself by 2050? Estimating cereal self-sufficiency to 2050. CCAFS Policy Brief 12. Wageningen, the Netherlands: CGIAR Research Program on Climate Change, Agriculture and Food Security (CCAFS). https://hdl.handle.net/10568/99019.

[12] Tesfaye B, Mesfin K, Tolera A, Gebresilasie H, Gebreyes G, Fite G. 2019. Some maize agronomic practices in Ethiopia: A review of research experiences and lessons from agronomic panel survey in Oromia and Amhara regions. African journal

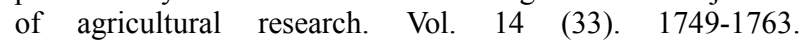
10.5897/AJAR2019.14338.

[13] You L, Wood-Sichra U, Fritz S, Guo Z, See L, and Koo J. 2014. Spatial Production Allocation Model (SPAM) 2005 v2.0. assessed on 1st, May 2020. Available from http://mapspam.info.

[14] Van Loon MP, Hijbeek R, ten Berge HFM, De Sy V, ten Broeke GA, Solomon D, van Ittersum MK. 2019. Impacts of intensifying or expanding cereal cropping in sub-Saharan Africa on greenhouse gas emissions and food security. Glob. Chang Biology 25: 3720-3730.

[15] Workneh Bekere 2021. From yield to application: nutrient requirement of maize for current and future production. Submitted (accepted). Afr.J.Agr. Res. 